TEME, г. XLIII, бр. 2, април - јун 2019, стр. 455-473

Оригинални научни рад $\quad$ https://doi.org/10.22190/TEME180119028D

Примљено: 19. 1. 2018.

UDK 338.48:159.923

Ревидирана верзија: 4. 10. 2018.

Одобрено за штампу: 25. 11. 2018.

\title{
MOTIVES, OBSESSION WITH DEATH AND BEHAVIORAL INTENTIONS IN DARK TOURISM
}

\author{
Darko Dimitrovski $^{1}$, Maja Luković ${ }^{2 *}$, Vladimir Senić ${ }^{1}$ \\ ${ }^{1}$ University of Kragujevac, Faculty of Hotel Management and Tourism, \\ Kragujevac, Serbia \\ ${ }^{2}$ University of Kragujevac, Faculty of Economics, Kragujevac, Serbia \\ mmilutinovic@kg.ac.rs
}

\begin{abstract}
Dark tourism varies in form from other types of tourism in that it involves visiting tragic sites or sites where death of historic significance occurred. This study explores the influence of the main motivators on behavioral intentions of those visiting dark tourism events by examining the impact of learning, socialization, relaxation and escape, emotional response and novelty on behavioral intentions, whilst variable death obsession is set as potential moderator of interdependence between independent variables and dependent variables. The findings suggest that learning, emotional response and novelty have a statistically significant impact on behavioral intentions, while death obsession is not seen as significant moderator. Purpose of research was to determine if death obsession as psychological trait have any influence on relation between motivation and behavioral intention in dark tourism event context.
\end{abstract}

Key words: Dark tourism, dark event, motives, death obsession, behavioral intention.

\section{МОТИВИ, ОПСЕДНУТОСТ СМРИУ И БИХЕВИОРАЛНЕ НАМЕРЕ У „МРАЧНОМ” ТУРИЗМУ}

\begin{abstract}
Апстракт
„Мрачни” туризам разликује се у форми од других типова туризама у томе што имплицира посету места на којима су се збили трагични догађаји или места која асоцирају на смрт историјских размера. У раду се истражују главни мотиви туриста који посећују места везана за „мрачни” туризам истраживањем утицаја образовања, социјализације, релаксације и бега од стварности, емоционалног одговора и жеље да се буде другачији на интенционално понашање посетилаца места „мрачног” туризма. Истовремено, варијабла опседнутости смрћу се у раду поставља као потенцијални узрок међузависности независних и зависних варијабли. Резултати истраживања показују да образовање, емоционални одговор и жеља да се буде другачији од других имају, статистички посматрано, значајан утицај на интенционално понашање
\end{abstract}


ове групе туриста, док се опседнутост смрћу не показује као битан мотив посете местима „мрачног” туризма. Циљ истраживања је постављен како би се утврдило да ли опседнутост смрћу, у смислу психолошке карактеристике, има било какав утицај на однос између мотивације и интенционалног понашања у контексту посета места „мрачног” туризма.

Кључне речи: „мрачни” туризам, догађај везан за „мрачни” туризам, мотиви, опседнутост смрћу, интенционално понашање.

\section{INTRODUCTION}

Travelling to and experiencing places associated with death is common within contemporary society (Wilson, 2008). This type of travel dates back to the eleventh century (Dale and Robinson, 2011), reaching its peak during the years of the end of the eighteenth century and the beginning of the nineteenth century (Seaton, 1999). Tarlow (2005) identifies dark tourism as a visit to a site where tragedies and historically significant deaths took place, but still continue to have an impact on our lives. Nowadays, it appears that the demand for dark tourism is on the increase (Sharpley, 2009).

Dark tourism literature is frequently broad in nature (Kim and Butler, 2014), so sites that present death can be seen as places for remembering, grieving or education; a particular spiritual experience; a means for building national identity; or simply sites of accidental visit (Logan \& Reeves, 2009; Slade, 2003).

Research into the reasons and purposes that drive the desire of tourists to seek out sites and experiences with such qualities is rather complex. Dark tourism visitors are, above all, led by different intensities in their of interest and fascination with death (Stone and Sharpley, 2008), but it is not yet clear to what extent the obsession with death is of importance when making a decision to visit such an 'attraction'. Nevertheless, no attempt has been made to explore relationship between dark tourism motivation and obsession with death of individual. Motives for visitation of places and events that are related to human suffering are increasingly shaped by individual reaction to the inevitability of human death.

Acknowledging the complexities related to engaging in dark tourism activities, this paper focuses on the motives of the visitors to dark tourism events, with a particular objective of determining why individuals visit events that commemorate or represent human suffering and tragedy. The aim is to narrow the gap that exists in current tourism literature, particularly when it comes to studying motives that have an impact on peoples' willingness to revisit such events and to share experiences with friends and acquaintances, specifying a role of death obsession as psychological trait in that relationship as a moderating variable. Furthermore, the research conducted represents a good starting point for future theoretical and empirical studies, in particular with regards to events related to dark tourism. 


\section{LITERATURE REVIEW}

Motivation in tourism has been and still attracts the considerable attention of tourism scholars, as understanding the motivational drivers in tourism will ease the further understanding of the tourism behavior. Motivation could be perceived as a psychological state that drives human behavior (Jang \& Wu, 2006). The most significant motivation theories that have been discussed and accepted by numerous tourism academics are: Maslow (1970) Hierarchy of needs theory, Dann's (1979) 'Push' and 'Pull' theory, Complexity Theory (Mayo \& Jarvis, 1981); the Dichotomous Model (Iso-Ahole, 1983) and the Travel Career Ladder (Pearce et al., 1988). Following theories have proposed similar motivational drivers nevertheless to the type of tourism activity. In accordance with the existing literature regarding tourism motivation and observed tourists behavior within the observed dark tourism event, motivational variables specific for the researched event have been proposed.

The focus of the study is the commemorative event 'The Great School Hour', traditionally held every year on 21 October in Kragujevac, Serbia, in memory of the several thousand Kragujevac citizens who were shot on that day in 1941 by the Nazis. Given that half a century elapsed from the tragic event, it was interesting to investigate whether the visitors of a manifestation have motives colored with personal death obsession experienced during commemorating a tragedy. Variables were chosen in the context of time distance. This was done due to an assumption that motives of visiting a manifestation that commemorates tragic events which happened more than fifty years ago are not necessarily linked to dark motives, but rather the motives are similar to those when visiting other types of manifestations. To confirm this assumption we included death obsession as a moderating variable in order to examine if death obsession moderates the relationship between motivation and behavioral intentions. Use of this variable can empirically verify whether motives linked to death prevail or not during visiting dark tourism manifestation, which represents a significant contribution of the study.

Learning. Taking into consideration that nowadays, more than ever, individuals travel to gain new knowledge, the educational mission of dark tourism events becomes more pronounced. The significance of the learning experience in dark tourism is acknowledged by many authors (Stone, 2006; Baldwin \& Sharpley, 2009; Walter, 2009, Cohen, 2011; Farmaki, 2013). Due to the immediate experience it provides, events related to great anguish are nowadays becoming more appealing to tourists. Dark tourism sites can offer better understanding through learning (Henderson, 2000; Lennon \& Foley, 2000) via actual sites of tragedy, commemorative events and exhibits. This represents a foundation for stimulating harmony and reconciliation, as well as understanding and learning through inclusive commemoration (Sharpley, 2009). Taking into consideration that learning 
plays an important role in dark tourism we propose the following hypothesis:

H1a: Learning has a positive influence on behavioral intentions.

Socialization. Socialization represents the desire to widen social contacts and it represents a very important aspect of many motivational studies in tourism (Lee et al., 2004; Chang, 2006). Crompton and McKay (1997) suggest that one of the reasons for visiting a particular event is, in fact, socialization. The significance of socialization as a motivational factor where events are concerned, even those of 'dark type', is not a surprise given that they draw large numbers of people with the same or similar interests. Several authors (Slade, 2003; Sharpley, 2005) agree that some tourists visiting death related sites are not aware of the 'dark attributes', as their visit is influenced by typical tourist motivation, among others including certain types of socialization, which leads to the following hypothesis being proposed:

H1b: Socialization has a positive influence on behavioral intentions.

Relaxation and escape. Several studies have shown that escape and relaxation are factors that impact whether an individual makes a decision to attend a particular event (Crompton \& McKay, 1997; Nicholson \& Pearce, 2001). Not all individuals who visit dark tourism sites are involved in dark experiences (Stone and Sharpley, 2008; Stone, 2012), but can have other motives for visiting this type of site, amongst which are relaxation and escape from daily routine. Certain visitors 'enjoy' memorial sites as they are usually quiet, vast green areas that offer escapism from the stress of everyday life, while others visit mass graves because of the rejuvenating power of contact with nature (Raine, 2013). Raine (2013) also introduces the category of 'retreaters' into the dark tourism typology - a type of visitor who uses the dark sites as a place for withdrawing from a city. Evidently, relaxation and escape surface as important factors for visiting 'dark tourism' sites. This leads to the proposition of the following hypothesis: intentions.

H1c: Relaxation and escape has a positive influence on behavioral

Emotional response. The interpretation of dark tourism depends on the intensity of interest and familiarity with events that occurred on the site, which represents a reason why certain visitors have a very personal and emotional relationship with particular sites and events (Biran et al., 2011; Sharpley, 2005). The same site will be experienced differently depending on the degree to which a tourist is psychologically and emotionally involved in the commemoration event (Dimitrovski et al., 2017). For visitors who have intimate emotional involvement with a memorial event (Brown, 2014), the presence itself can be more than 'thought out', since by participating in the memorial activity instances of self-actualization come back (Cohen, 2008). Given this, we propose the following hypothesis: intentions.

H1d: Emotional response has a positive influence on behavioral 
Novelty/Uniqueness. Novelty as motivation factor in this study comprises human need for search for uniqueness and authenticity. Events are an important motivator in travel and tourism and happiness of visitors is enhanced by the event's uniqueness (Kruger, Saayman and Ellis, 2014). With regards to studies dealing with dark tourism, Selwyn (1996) in his research on Yad Vashem visitors describes uniqueness as a very emotional experience. The authenticity of dark tourism sites and the meanings tied to them is also viewed as an important element that impacts the empathy and sympathy of visitors (Miles, 2002; Sharpley and Stone, 2009). A visit to a dark tourism site is often viewed as a 'unique activity' (Best, 2007). Considering that novelty surfaces as a significant visiting factor for dark tourism events, we propose the following hypothesis: intentions.

H1e: Novelty/Uniqueness has a positive influence on behavioral

Death obsession. Death as a topic is constantly present in everyday life, mainly through the media, popular culture and also, recently, through tourism (Stone, 2012; Stone and Sharpley, 2008). Seaton (1996) claims that dark tourism results from the fact that people are motivated by their desire for symbolic encounters with death. Memorials figure as places which allow people to engage in symbolic encounters with death within safe and comfortable tourist settings (Tarlow, 2005; Stone, 2012). Walter (2009) names mass graves and memorials as places where people go to experience 'memento mori' and face death.

Abdel-Khalek (1998) introduced the notion ,death obsession“ with the idea to assess the importance of preoccupation, drives and constant ideas connected with death. Death obsession is proved to have statistical significant relationship towards with anxiety, obsession-compulsion and pessimism positively and with optimism negatively (Abdel-Khalek \& Lester, 2002) and statistically significant negative correlation with an intrinsic orientation toward religion (Maltby \& Day, 2000). Death inevitability causes many disagreable human forms of behavior from prejudice and aggresive behavior to war and terrorism support (Greenberg, Solomon, \& Arndt, 2008). Therefore, it was interesting to set death obsession as psychological trait in dark event context with assumption that if obsession with death of individual is more pronounced, it will influence stronger connection between motivators and behavioral intention towards dark events. As preoccupation with death during dark tourism experience is already put in the question (Isaac and Çakmak, 2013), determination of death obsession to change relationship (moderate) between motives and behavioral intentions will be of great importance. In line with this, the following hypotheses are proposed: 
- H2a: Death obsession has a significant moderating role in the relationship between learning and education and behavioral intentions.

- H2b: Death obsession has a significant moderating role in the relationship between socialization and behavioral intentions.

- H2c: Death obsession has a significant moderating role in the relationship between relaxation and escape and behavioral intentions.

- H2d: Death obsession has a significant moderating role in the relationship between emotional response and behavioral intentions.

- H2e: Death obsession has a significant moderating role in the relationship between novelty/uniqueness and behavioral intentions.

Behavioral intentions. Some studies (Bamberg et al., 2003; Hrubes et al., 2001) reveal that the attitude of tourists significantly influences behavioral intentions (Wang \& Hsu, 2010). Best (2007) suggests that the emotions that tourists experience while visiting sites related to catastrophe and death can shape behavioral intentions through revisit intentions and willingness to recommend. For sites related to death and torment, it is of great significance to generate positive word-of-mouth and revisit intentions (Muzaini, Teo and Yeoh, 2007). In a study of concentration camps, it was found that the emotional reaction of visitors is a good predictor of revisit intentions and positive word-of-mouth behavior (Nawijn \& Fricke, 2013).

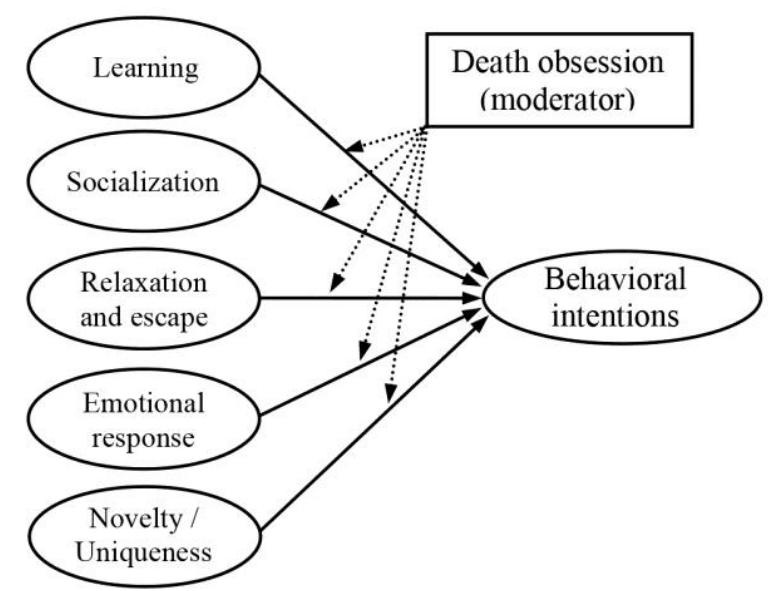

Figure 1. Proposed research model

The model consists of five independent variables - learning and education; socialization; relaxation and escape; emotional response and novelty/uniqueness. Death obsession is a moderating variable and behavioral intention is represented as a dependent variable. The model shown on Figure 
1 has the purpose to statistically define important causes of a visitor's behavioral intentions, as well as the goal to explore the moderating role of death obsession in a set of relationships of independent variables with behavioral intentions.

\section{METHODOLOGY}

The study was conducted via a convenience sample of 287 respondents. The respondents were visitors of the commemorative event 'The Great School Hour'. In such a context, the aim was to determine the primary reasons as to why visitors wanted to participate in the event, as well as recommend this event to their friends and acquaintances, whilst variable death obsession is set as potential moderator of interdependence between independent variables and dependent variables.

Commemorative event 'The Great School Hour' is of great national and international importance as it is globally known as site of the greatest massacre in World War II, so there is great number of domestic and international visitors. Focus of our research was on visitors below forty years, as they were not born in time of tragedy. Examining motivations of visitors with lack of direct knowledge and experience of event is important to understand the nature of the relationship between the younger visitors and the event.

Upon the finishing of the commemoration, event participants were approached by surveyors. Respondents gave answers to 23 questions grouped into seven latent variables. Specifically, respondents demonstrated the level of agreement with the statements offered on a seven-point Likert scale (1 - I completely disagree; 7 - I completely agree). Prior to distribution, the questionnaire was tested with the aim to formulate statements that will be clear and unambiguous to respondents. Several university professors were involved in the focus group in order to assess the structure of the questionnaire. Afterwards, the questionnaire was given to a sample of approximately 30 respondents who pre-tested it. Through the feedback from this initial surveying, several minor modifications were made to the initial statements, providing the final version of the questionnaire.

In order to propose the questionnaire that will fully reflect the unique nature of the dark tourism event, the examination of the existing knowledge and motivational variable were assessed as a result of the focus group and pre-test. Thus, some of the motivational variables were adapted to correspond to the research goals and reflect the fit of the model. Thus, some of the variables and items common for the tourism motivation were discarded as unimportant. Each variable of the devised research model was measured with three of four statements. Items were selected through a review of literature. Learning was measured by four statements based on several studies (Poria et. al., 2004; Kang et. al., 2012; Winter, 2011). 
Socialization was measured by three items based on next studies (Lee et. al., 2004; Nicholson and Pearce, 2001). Relaxation and escape was measured by four items based on a number of studies (Lee et. al., 2004; Nicholson and Pearce, 2001). Emotional response consists of three statements (Poria et. al., 2004; Poria et. al., 2006a; Poria et. al., 2006b). Novelty/Uniqueness also consists of three statements (Nicholson and Pearce, 2001). All the statements were adapted for the purposes of this study.

Death obsession as a moderator variable consists of three statements from the Death Obsession Scale developed by Abdel-Khalek (1998). The final choice of the items used in the study was based on the results of the focus group. Only variables that fully reflect the specific nature of the event were taken into consideration. The use of this scale has significant impact on empirical studies aiming to research preoccupation with death, and in the case of this study, the scale was used to determine to which extent preoccupation with death and thoughts about death are important for experiencing dark tourism events. In the study an analogy was made relating to research completed by Abdel-Khalek (1998), given the fact that the sample mainly consisted of individuals younger than 40 years.

Behavioral intention was measured by statements found in literature that deal with issues related to dark tourism (Nawijn and Fricke, 2013; Yoon et. al., 2010). The statements that were related to behavioral intentions consisted of two statements that refer to revisit intentions and two statements referring to willingness to recommend.

The Statistical Package for Social Sciences (version 20.0) and AMOS (version 18.0) were used in the data analysis completion. The implemented statistical analysis included reliability, confirmative factor analysis and moderating regression analysis. The first step, relying on Cronbach's alpha coefficient values, included the measurement of the reliability and inner statements stability used to assess latent variables. The second step consisted of the confirmative factor analysis which was applied in order to test the suitability of the research model. Moderated regression analysis was used for the main and interaction effects to be tested. Therefore, independent variables were initially centered, and mutually multiplied afterwards, in order to avoid the possible issue of multi-co-linearity, which can surface when calculating interaction effects.

\section{RESULTS}

According to the principles of the descriptive statistics this sample pointed out that $56.4 \%$ percent of respondents were female and $43.6 \%$ percent were male, considering the age structure of the used sample consisted of relatively young people who are younger than 40 years of age. Due to the nature of the event visited by respondents, the deliberate intention was to survey only those who were born 30 or more years after 
the end of World War II. Namely, these individuals do not have a direct relation to the tragedy which occurred in 1941, given that they live in a different time. It is therefore interesting to explore their attitudes regarding the event being commemorated. In that respect, all respondents were divided into four age categories, with most respondents falling into the 1824 years old category $(28.6 \%)$. The second most respondents fell into the 25-30 years old category (25.8\%) and then a group that consists of those who are 36-40 years old (24.7\%). A somewhat lower percent of respondents fell into the 31-35 years old group (20.9\%). The largest portion of respondents had completed high school (51.6\%). Respondents with a bachelor's degree account for $35.5 \%$ of the sample, while $12.9 \%$ of the sample has an associate's degree (Table 1).

Table 1. Descriptive statistics of respondents' characteristics $(n=287)$.

\begin{tabular}{lcc}
\hline Demographics & Frequency & $\%$ \\
\hline Gender & & \\
$\quad$ Male & 125 & 43.6 \\
$\quad$ Female & 162 & 56.4 \\
Age & & \\
$18-24$ & 82 & 28.6 \\
$25-30$ & 74 & 25.8 \\
$31-35$ & 60 & 20.9 \\
$36-40$ & 71 & 24.7 \\
Education & & \\
High school diploma & 148 & 51.6 \\
Associate's degree & 37 & 12.9 \\
Bachelor's degree or higher & 102 & 35.5 \\
\hline
\end{tabular}

At the very beginning of the statistical analysis item to total correlation was employed in order to decrease the initial number of statements used. Based on the results, it was decided that two statements (one used to measure the 'learning and education' variable and the other used to measure the 'socialization' variable) would be excluded. After excluding these two statements, reliability analysis and confirmative factor analysis was conducted.

Table 2 shows the values for Cronbach's alpha coefficient for the seven variables of the conceptualized research model. All variables have an adequate level of reliability, given that the values of Cronbach's alpha coefficient are greater than the necessary 0.7 threshold (Nunnally, 1978). The results reveal that the greatest degree of reliability is apparent with the variable 'relaxation' (Cronbach's alpha $=0.92)$, while variable 'socialization' has the lowest degree of reliability (Cronbach's alpha $=0.77$ ). 
Table 2. Reliability of model variables

(Cronbach's alpha coefficient values).

\begin{tabular}{lc}
\hline Variable & Cronbach's alpha \\
\hline Learning & 0.88 \\
Socialization & 0.77 \\
Relaxation & 0.92 \\
Emotional response & 0.83 \\
Novelty/Uniqueness & 0.87 \\
Death obsession & 0.87 \\
Behavioral intentions & 0.84 \\
\hline
\end{tabular}

The testing of the fit of the conceptualized model was undertaken via the use of confirmative factor analysis, with the results showing that the proposed model reasonably fits the data. The value of the ratio $\chi^{2} / \mathrm{df}(1.88)$ is lower than the threshold of three which was proposed by Bagozzi and Yi (1988). Other fit indices also have adequate values (Comparative Fit Index = 0.949; The Tucker-Lewis Index = 0.939; Incremental Fit Index =0.950; The Root Mean Square Error of Approximation = 0.055). According to the recommendation made by Byrne (1998), the first three indices (CFI, TLI and IFI) must be greater 0.9. Additionally, it is desirable that the value of RMSEA coefficient is within the range of 0.05-0.08 (Hair et. al., 2006), which is the case with results obtained. The results of the confirmative factor analysis are shown in Table 3.

The suggested model has an acceptable level of convergent validity, discriminatory validity and composite reliability. The average variance extracted (AVE) of all variables is greater than 0.5: learning (0.71), socialization (0.54), relaxation (0.73), emotional response (0.62), novelty/ uniqueness (0.71), death obsession (0.68) and behavioral intentions (0.57). In this way, the model meets the requirements of convergent validity (Fornell and Larcker, 1981). Given that the AVE value of every individual statement is greater than the squared coefficient correlation between the given and other statements, discriminatory validity is assured. The model has a quality of composite reliability (CR), given that the $\mathrm{CR}$ value for each variable is greater than the threshold of 0.6 (Bagozzi and Yi, 1988). Specifically, the CR of all statements is within the $0.78-0.91$ range.

The regression analysis was used in order to test the main and interaction effects. The usage of this type of the analysis determined importance of the independent variables influence on behavioral intentions, as well as on moderating role of 'death obsession' and relationship between independent variables and behavioral intentions. The regression analysis was carried out in two steps. In that context, regression analysis was then conducted in two steps. The first step included calculation of the main effects (Model 1). The second step included the measurement of interaction effects (Model 2). The issue of the multi-co-linearity preceded the standardized 
regression coefficient analysis. The fact that all variance inflation factor values were lower than five excluded the multi-co-linearity from the further researching process of the study.

Table 3. Results of confirmatory factor analysis

\begin{tabular}{|c|c|}
\hline Constructs and items (AVE and CR) & Loading \\
\hline \multicolumn{2}{|l|}{ Learning and Education $(0.71 ; 0.88)$} \\
\hline Increase my knowledge about the event & 0.790 \\
\hline Increase my knowledge about national history & 0.853 \\
\hline Expand my interests about October tragedy & 0.891 \\
\hline \multicolumn{2}{|l|}{ Socialization $(0.54 ; 0.78)$} \\
\hline Be with people of similar interest & 0.670 \\
\hline Meet different people from all over the world & 0.724 \\
\hline Share my experience with others & 0.813 \\
\hline \multicolumn{2}{|l|}{ Relaxation and escapism $(0.73 ; 0.91)$} \\
\hline Relieve daily stress & 0.802 \\
\hline Relax mentally & 0.813 \\
\hline Get away from responsibilities of my everyday life & 0.923 \\
\hline Relax in a nice environment & 0.875 \\
\hline \multicolumn{2}{|l|}{ Emotional Response $(0.62 ; 0.83)$} \\
\hline Feel emotionally involved & 0.750 \\
\hline Pray for victims of genocide & 0.833 \\
\hline Share the pain and sorrow with the families of victims & 0.782 \\
\hline \multicolumn{2}{|l|}{ Novelty/Uniqueness $(0.71 ; 0.88)$} \\
\hline Experience this kind of event & 0.736 \\
\hline Be part of a unique event & 0.959 \\
\hline To be part of this proud and festive atmosphere & 0.820 \\
\hline \multicolumn{2}{|l|}{ Death Obsession $(0.68 ; 0.86)$} \\
\hline During this event I think about death continuously & 0.845 \\
\hline $\begin{array}{l}\text { During this event some questions about death come to my } \\
\text { mind which I am unable to answer }\end{array}$ & 0.837 \\
\hline During this event thinking about death preoccupies me & 0.794 \\
\hline \multicolumn{2}{|l|}{ Behavioral Intentions $(0.57 ; 0.84)$} \\
\hline I would like to visit this event again in the future & 0.770 \\
\hline I will keep attending the event & 0.797 \\
\hline I will say positive things about this event to other people & 0.673 \\
\hline I would recommend this event to others & 0.768 \\
\hline
\end{tabular}

The analysis of main effects shows that three independent variables have a statistically significant impact on behavioral intentions: learning ( $\beta$ $=0.204, \mathrm{p}<0.01)$, emotional response $(\beta=0.192, \mathrm{p}<0.01)$ and novelty/uniqueness $(\beta=0.284, p<0.01)$. Therefore, hypotheses H1a, H1d and H1e were confirmed, with variable 'novelty' having the strongest impact on behavioral intentions. It is important to point out that the research results did not confirm a significant impact of socialization and 
relaxation on behavioral intention, thus excluding hypotheses $\mathrm{H} 1 \mathrm{~b}$ and H1c. It can be inferred that people are willing to revisit the event, as well as talk to others about it, mainly because of its uniqueness, given the fact that the event is closely related to the city's cultural and historical heritage and has an important place in the history of the Serbian people. People also expressed a desire to visit the event in order to gain additional knowledge about that time, as well as the fact that they still feel grief as a result of that tragic event. The results of the regression analysis are shown in Table 4.

Table 4. Results of moderated regression analysis (dependent variable: behavioral intentions)

\begin{tabular}{lcc}
\hline & Model 1 & Model 2 \\
\hline Independent variables & & \\
Learning & $0.204^{* *}$ & $0.202^{* *}$ \\
Socialization & -0.037 & -0.036 \\
Relaxation & -0.042 & -0.043 \\
Emotional Response & $0.192^{* * *}$ & $0.186^{* *}$ \\
Novelty/Uniqueness & $0.284^{* *}$ & $0.285^{* *}$ \\
Death Obsession & 0.062 & 0.062 \\
\hline Interaction & \\
Learning * Death Obsession & 0.049 \\
Socialization * Death Obsession & 0.002 \\
Relaxation * Death Obsession & 0.013 \\
Emotional Response * Death Obsession & 0.009 \\
Novelty/Uniqueness * Death Obsession & 0.017 \\
\hline \multicolumn{2}{c}{ Note: Standardized regression coefficients are reported } \\
in columns marked Model 1, Model 2; ${ }^{* *} \mathrm{p}<0.01$ \\
\hline
\end{tabular}

The second step considered measuring interaction effects. The death obsession was used as a moderating variable. The usage of this variable influenced the relationship strength between other variables and behavioral intentions. Interestingly, none of the five tested interaction effects surfaced as statistically significant, thus rejecting hypotheses $\mathrm{H} 2 \mathrm{a}, \mathrm{H} 2 \mathrm{~b}, \mathrm{H} 2 \mathrm{c}, \mathrm{H} 2 \mathrm{~d}$ and H2e. Therefore, it can be concluded that death obsession does not have a significant moderating role in the relationship between independent variables and behavioral intentions. Within the preliminary descriptive analysis it was determined that respondents expressed a rather low level of death obsession while attending the event. Results suggest that death obsession have no significant effect on behavioral intention as well. Namely, given that the sample was of relatively younger people who were born more than 30 years after the tragic event, it is obvious that it did not manifest within them associations of death nor did it create such thoughts. Such a result is probably the outcome of the fact that the respondents in this study live in a different, perhaps more peaceful world, and therefore have more serene lives than their ancestors who lived during World War II. 


\section{DISCUSSION AND IMPLICATIONS}

Through the observation of prior studies it can be seen that the impact of learning and education, socialization, relaxation and escape, emotional response and novelty/uniqueness had been seldom tested in the context of dark tourism events. The originality of the study is also due to the 'death obsession' variable, which was used as a potential moderator between independent variables and the dependant variable - therefore, testing not only the main, but also the interaction effects, additionally contributes to existing literature.

The findings revealed that visitors are willing to return to the event mainly because of its novelty and uniqueness and their wish to learn, but also because they are emotionally touched by the events of World War II. In terms of emotional response, similar results can be found in the study by Nawijn and Fricke (2013), who showed that the more emphasized the emotions are, the greater is the possibility for tourists to return to a given site and recommend it to their friends and acquaintances. It is important to stress the fact that people do not come to this event for the purpose of escape or relaxation, despite the fact that the sample consists mainly of younger people. Even though it is considered a tourism 'event', it does not create a sense of relaxation or pleasure among visitors. Yet, because of the need to pay respect to their own culture and history, people are ready to visit the event in the future, and talk about it to their friends and acquaintances. In addition, people do not attend this event for the purpose of socializing or meeting other people. In that context, relaxation and socialization are not factors that have a significant impact on behavioral intentions.

However, the results of the research, did not confirm the significant moderating role of death obsession as statistically significant. Despite the fact that the event was emotional for its visitors and that visitors expressed the desire to learn more about historical events, respondents did not convey an obsession with death during the event and this variable did not change the strength of the relationship between independent variables and behavioral intentions. Such an outcome is probably the result of the fact that the event attendees grew up in a more peaceful time and therefore did not feel any significant tension during the event itself. The current generation of memorial visitors differs significantly from the wartime generation, particularly in their lack of direct knowledge and experience of events and contact with those who served in the war (Winter, 2006). Indeed, recent tragedies can be seen as more intense due to the level of empathy directed towards those who lived through tragedy, which in turn initiates a greater level of death obsession during dark tourism event (Miles, 2002). The outcomes of the research can be interpreted in light of Ashworth's (2004) conclusion, who states that in a motivational study it is very difficult to determine 
fascination with death because of the fact that people, generally speaking, are not willing to reveal some socially less acceptable emotions and motives.

The need to define different types of dark tourism visitors and the factors that influence their experience are of essential importance for the further development of dark tourism. Seaton (2009) suggests that dark tourism sites are unique areas that are different from all other tourist places due to their evolutional variety. Timothy and Boyd (2003) conclude that tourists can come from different regions with different needs, expectations and education levels, which the variations documented must be taken into account and an efficient plan that allows for different levels of interpretation, must be developed.

These useful managerial guidelines emphasize the need for the organizers of such events to strongly accent emotional experience in their program, since it has a very important role in dark tourism. A commemorative event should include some artistic performance which may have an influence on increasing emotional ties between visitors and a site itself (Dimitrovski et al., 2017).

The findings of the study introduce practical implications for event managers, since commemorative events are not only places where people go to pay tribute to victims, but also that there is a wider audience that needs to be taken into consideration in the organization of the event itself. When developing this type of tourism, managers need to pay particular attention to maintain the authenticity of the site, especially its natural surrounding - which is an inseparable component of the event. The uniqueness of the event and its artistic program is one of the more important aspects that demands careful planning by managers, since it represents the single most important element for maintaining a high attractiveness level of the event among visitors and to convey a strong anti-war message. On the other hand, marketing activities often need to be held at minimum, mainly for the ethical issues that may arise from promoting a site of tragedy.

\section{REFERENCES}

Abdel-Khalek, A. M. (1998). The structure and measurement of death obsession. Personality and Individual Differences, 24(2), 159-165.

Abdel-Khalek, A. M., \& Lester, D. (2006). Optimism and pessimism in Kuwaiti and American college students. International Journal of Social Psychiatry, 52, 110-126.

Ashworth, G. (2004). Tourism and the heritage of atrocity: managing the heritage of South Africa for entertainment. In T. Singh (Eds.), New horizons in tourism: Strange experiences and stranger practices (pp. 95-108). Wallingford, UK: CAB International.

Bagozzi, R.P., \& Yi, Y. (1988). On the evaluation of structural equation models. Journal of the Academy of Marketing Science, 16(1), 74-94. 
Baldwin, F., \& Sharpley, R. (2009). Battlefield tourism: bringing organised violence. In R. Sharpley, \& P. Stone (Eds.), The darker side of travel (pp. 186-206). Bristol: Channel View.

Bamberg, S., Ajzen, I., \& Schmidt, P. (2003). Choice of travel mode in the theory of planned behavior: The roles of past behavior, habit, and reasoned action. Basic and Applied Social Psychology, 25(3), 175-188.

Best M. (2007). Norfolk Island: thanatourism, history and visitor emotions. Shima: The International Journal of Research into Island Cultures, 1(2), 30-48.

Biran, A., Poria, Y., \& Oren, G. (2011). Sought experiences at dark heritage sites. Annals of Tourism Research, 38(3), 820-841.

Brown, L. (2014). Memorials to the victims of Nazism: The impact on tourists in Berlin. Journal of Tourism and Cultural Change. 13(3), 244-260. DOI: 10.1080/14766825.2014.946423

Byrne, B.M. (1998). Structural equation modeling with LISREL, PRELIS and SIMPLIS: Basic concepts, applications and programming. Mahwah. New Jersey: Lawrence Erlbaum Associates.

Chang, J. (2006). Segmenting tourists to aboriginal cultural festivals: an example in the Rukai tribal area, Taiwan. Tourism Management, 27(6), 1224-1234.

Cohen, E. (2011). Educational dark tourism at an in populo site: The Holocaust Museum in Jerusalem. Annals of Tourism Research, 38(1), 193-209.

Cohen, S. (2008). Know thyself? Assimilating the classical leisure ideal, selfactualisation, flow experience and existential authenticity. In P. Gilchrist, \& B. Wheaton (Eds.), Whatever happened to the leisure society? Theory, debate and policy (pp. 165-180). Eastbourne: Leisure Studies Association.

Crompton, J., \& McKay, S. (1997). Motives of visitors attending festival events. Annals of Tourism Research, 24(2), 425-439.

Dale, C., \& Robinson, N. (2011). Dark tourism. In P. Robinson, S. Heitmann, \& P. Dieke (Eds.), Research themes for tourism. Wallingford, UK: CAB International.

Dimitrovski, D., Senić, V., Marić, D., \& Marinković, V. (2017). Commemorative Events at Destination Memorials - A Dark (Heritage) Tourism Context. International Journal of Heritage Studies, 23(8), 695-708.

Dann, M. S. (1977). Anomie, ego-enhancement and tourism. Annals of Tourism Research, 4, 184-194.

Farmaki, A. (2013). Dark tourism revisited: a supply/demand conceptualization. International Journal of Culture, Tourism and Hospitality Research, 7(3), 281-292.

Fornell, C., \& Larcker, D.F. (1981). Evaluating structural equation models with unobservable variables and measurement error. Journal of Marketing Research, 18(1), 39-80.

Greenberg, J., Solomon, S., \& Arndt, J. (2008). A basic but uniquely human motivation: Terror management. In J. Y. Shah, \& W. L. Gardner (Eds.), Handbook of motivation science (pp.114-134). New York, NY: Guilford.

Hair, Jr. J. F., Black, W. C, Babin, B., Anderson R., \& Tatham, R. (2006). Multivariate Data Analysis (6th ed.). Upper Saddle River, NJ: Prentice Hall.

Henderson, J. (2000). War as a tourist attraction: The case of Vietnam. International Journal of Tourism Research, 2(4), 269-280.

Hrubes, D., Ajzen, I., \& Daigle, J. (2001). Predicting hunting intentions and behavior: An application of the theory of planned behavior. Leisure Sciences, 23(3), 165-178.

Isaac, R. K., \& Çakmak, E. (2013). Understanding visitor's motivation at sites of death and disaster: the case of former transit camp Westerbork, the Netherlands. Current Issues in Tourism, 17(2), 164-179.

Iso-Ahola, S. E. (1983). Towards a social psychology of recreational travel. Leisure Studies, 2, 45-56. 
Jang, S., \& Wu, C.-M. E. (2006). Seniors' travel motivation and the influential factors: An examination of Taiwanese seniors. Tourism Management, 27(2), 306-316.

Kang, E. J., Scott, N., Lee, T. J., \& Ballantyne, R. (2012). Benefits of visiting a dark tourism site: The case of the Jeju April 3rd Peace Park, Korea, Tourism Management, 33(2), 257-265.

Kim, S., \& Butler, G., (2014). Local Community Perspectives towards Dark Tourism Development: The Case of Snowtown, South Australia. Journal of Tourism and Cultural Change, 13(1), 78-89.

Kruger, S., Saayman, M., \& Ellis, S. (2014). The influence of travel motives on visitor happiness attending a Wedding Expo, Journal of Travel \& Tourism Marketing, 31(5), 649-665.

Lee, C. K., Lee, Y. K., \& Wicks, B. E. (2004). Segmentation of festival motivation by nationality and satisfaction. Tourism Management, 25(1), 61-70.

Lennon, J. J., \& Foley, M. (2000). Dark tourism. London: Continuum.

Logan, W., \& Reeves, K. (2009). Introduction: remembering places of pain and shame. In W. Logan, \& K. Reeves (Eds.), Places of pain and shame: Dealing with 'difficult heritage' (pp. 1-14). London: Routledge.

Maltby, J., \& Day, L. (2000). Religious orientation and death obsession. Journal of Genetic Psychology, 16, 122-124.

Maslow, A. H. (1970). Motivation and Personality (2nd ed.). New York: Harper and Row.

Mayo, E. J., \& Jarvis, L. P. (1981). The psychology of leisure travel. Effective marketing and selling of travel services. Boston, MA: CBI Publishing Company, Inc.

Miles, W. F. S. (2002). Auschwitz: Museum interpretation and darker tourism. Annals of Tourism Research, 29(4), 1175-1178

Muzaini, H., Teo, P., \& Yeoh, B. S. A. (2007). Intimations of postmodernity in dark tourism: The fate of history at Fort Siloso, Singapore. Journal of Tourism and Cultural Change, 5(1), 28-44.

Nawijn J., \& Fricke, M. (2013). Visitor emotions and behavioral intentions: the case of concentration camp memorial Neuengamme. International Journal of Tourism Research. 17(3), 221-228. DOI: 10.1002/jtr.1977

Nicholson, R., \& Pearce, D. (2001). Why do people attend events: A comparative analysis of visitor motivations at four South Island events. Journal of Travel Research, 39(4), 449-460.

Nunnally, J.C. (1978). Introduction to psychological measurement. New York: McGraw-Hill.

Pearce, P. A., M. Morrison, \& J. L. Rutledge. (1998). Tourism: Bridges across Continents. Sydney, Australia: McGraw-Hill.

Poria, Y., Butler, R., \& Airey, D. (2006a). Tourist perceptions of heritage exhibits: a comparative study from Israel. Journal of Heritage Tourism, 1(1), 51-72.

Poria, Y., Reichel, A., \& Biran, A. (2006b). Heritage site perceptions and motivations to visit. Journal of Travel Research, 44(3), 318-326.

Poria, Y., Butler, R., \& Airey, D. (2004). Links between tourists, heritage, and reasons for visiting heritage sites. Journal of Travel Research, 43(1), 19-28.

Raine, R. (2013). A dark tourist spectrum. International Journal of Culture, Tourism and Hospitality Research, 7(3), 242-256.

Seaton, A. (1996). Guided by the dark: from thanatopsis to thanatourism. International Journal of Heritage Studies, 2(4), 234-244.

Seaton, A. (1999). War and thanatourism: Waterloo 1815-1914. Annals of Tourism Research, 26(1), 130-158. 
Seaton, A. (2009). Purposeful otherness: Approaches to the management of thanatourism. In R. Sharpley, \& P. Stone (Eds.), The darker side of travel: The theory and practice of dark tourism (pp. 75-108). Bristol: Channel View Publications.

Seaton, A., \& Lennon, J.J. (2004). Moral panics, ulterior motives and ulterior desires: thanatourism in the early 21 st century. In T. V. Singh (Eds.), New horizons in tourism: Strange experiences and stranger practices (pp. 63-82). Wallingford, UK: CAB International.

Selwyn, T. (1996). The tourist image: Myths and myth making in tourism. Chichester: John Wiley \& Sons.

Sharpley, R., \& Stone, P. R. (2009). The darker side of travel: The theory and practice of dark tourism. Bristol: Channel View Publications.

Sharpley, R. (2005). Travels to the edge of darkness: towards a typology of 'dark tourism'. In C. Ryan, S. Page, \& M. Aicken (Eds.), Taking tourism to the limits: Issues, concepts and managerial perspectives (pp. 187-198). Amsterdam: Elsevier.

Sharpley, R. (2009). Shedding light on dark tourism: an introduction. In R. Sharpley \& P. Stone (Eds.), The darker side of travel: The theory and practice of dark tourism (pp. 3-22). Bristol: Channel View Publications.

Slade, P. (2003). Gallipoli thanatourism: The meaning of ANZAC. Annals of Tourism Research, 30(4), 779-794.

Stone, P. (2006). A dark tourism spectrum: towards a typology of death and macabre related tourist sites, attractions and exhibitions. Tourism: An Interdisciplinary International Journal, 54(2), 145-160.

Stone, P., \& Sharpley, R. (2008). Consuming dark tourism: a thanatological perspective. Annals of Tourism Research, 35(2), 574-595.

Stone, P. R. (2012). Dark tourism as 'mortality capital': The case of Ground Zero and the significant other dead. In R. Sharpley \& P. R. Stone (Eds.), The contemporary tourist experience: Concepts and consequences (pp. 30-45). Abingdon, Oxon: Routledge.

Tarlow, P. E. (2005). Dark tourism: the appealing 'dark' side of tourism and more. In M. Novelli (Eds.), Niche tourism: Contemporary issues, trends and cases (pp. 4758). Amsterdam: Elsevier.

Timothy, D., \& Boyd, S. (2003). Heritage tourism. Harlow: Prentice Hall.

Walter, T. (2009). Dark tourism: Mediating between the dead and the living. In R. Sharpley, \& P. R. Stone (Eds.), The darker side of travel: The theory and practice of dark tourism (pp. 39-55). Bristol: Channel View Publications.

Wang, C-Y., \& Hsu, M. (2010). The relationships of destination image, satisfaction, and behavioral intentions: An integrated model. Journal of Travel \& Tourism Marketing, 27(8), 829-843.

Wilson, J. (2008). Prison: Cultural memory of dark tourism. New York, NY: Peter Lang.

Winter, J. (2006). Remembering war: The Great War between memory and history in the XX century. New Haven, CT: Yale University Press.

Winter, C. (2011). Battlefield visitor motivations: Explorations in the Great War town of Ieper, Belgium. International Journal of Tourism Research, 13(2), 164-176.

Yoon, Y.-S., Lee, J.-S., \& Lee, C.-K. (2010). Measuring festival quality and value affecting visitors' satisfaction and loyalty using a structural approach. International Journal of Hospitality Management, 29(2), 335-342. 


\title{
МОТИВИ, ОПСЕДНУТОСТ СМРЋУ И БИХЕВИОРАЛНЕ НАМЕРЕ У „МРАЧНОМ” ТУРИЗМУ
}

\author{
Дарко Димитровски ${ }^{1}$, Маја Луковић $^{2}$, Владимир Сенић $^{1}$ \\ ${ }^{1}$ Универзитет у Крагујевцу, Факултет за хотелијерство и туризам, Крагујевац, \\ Србија \\ ${ }^{2}$ Универзитет у Крагујевцу, Економски факултет, Крагујевац, Србија
}

\section{Резиме}

Проучавањем мноштва наведених истраживања, јасно се може видети да је утицај учења и образовања, социјализације, одмора као релаксације и као бега од реалности, емоционалног одговора и жеље да се буде другачији врло ретко изучаван тестирањем у контексту догађаја везаних за мрачни туризам. Оригиналност ове студије састоји се управо у коришћењу варијабле „опседнутости смрћу" као потенцијалног модератора између независних варијабли и зависне варијабле, односно самим тестирањем не само главних ефеката већ и ефеката интеракције које додатно доприносе јединствености ове студије.

Открића показују да се посетиоци радо враћају на догађаје везане за мрачни туризам углавном због њихове јединствености и жеље самих посетилаца да науче нешто више, али исто тако и из разлога емотивног реаговања на догађаје везане за Други светски рат. Важно је, стога, нагласити да људи не долазе на овај догађај због одмора као релаксације или бега од реалности, иако се узорак коришћен у истраживању углавном састоји од млађе популације. Иако се посета оваквом месту може тумачити као туристички „догађај”, она у себи не садржи импликације одмора и задовољства код посетилаца. Из жеље да одају поштовање својој историји, односно таквим и сличним догађајима из историје и културе, људи су вољни да посете таква места и да утиске својих посета пренесу својим пријатељима и познаницима. Исто тако, људи не посећују оваква места из разлога социјализације или сусрета са другим људима. У том контексту, одмор као релаксација или као вид социјализације нису фактори који имају значајан утицај на бихевиоралне намере.

Међутим, резултати овог истраживања нису показали значајну статистички посматрану модераторску улогу опседнутости смрћу. Упркос чињеници да је догађај имао емоционални утицај на посетиоце и да су посетиоци показали жељу да науче нешто више о историјским догађајима, испитаници нису показали опседнутост смрћу током самог догађаја, тако да ова варијабла није могла да утиче на јаку везу између независних варијабли и бихевиоралних намера. Овакав исход вероватно је резултат чињенице да су посетиоци одрастали у неком мирнијем времену и стога нису могли да осете неку значајнију тензију током самог догађаја. Данашња генерација посетилаца меморијаних места у великој мери се разликује од ратних генерација, нарочито због недостатка директне спознаје и искуства таквих догађаја, као и контакта са онима који су директно учествовали у рату (Винтер, 2006). С друге стране, скорашње трагедије могу се посматрати као далеко интензивније у вези са нивоом емпатије усмерене ка онима који су трагедију проживели, што управо иницира виши ниво опседнутости смрћу током догађаја везаних за мрачни туризам (Мајлс, 2002). Резултате истраживања могуће је интерпретирати у светлу Ешвортовог (2004) закључка, који тврди да је у мотивационом истраживању врло тешко одредити фасцинацију смрћу ако се у обзир узме чињеница да људи не желе да открију или признају мање друштвено прихватљиве емоције и мотивације. 
Потреба за дефинисањем различитих типова посетилаца када је реч о мрачном туризму и фактора који утичу на њихова искуства од пресудне су важности за даље развијање мрачног туризма. Ситон (2009) указује на то да су места везана за мрачни туризам јединствена јер се разликују од свих других туристичких места по својој еволуционој разноврсности. Тимоти и Бојд (2003) закључују да туристи могу да долазе из различитих региона са различитим потребама, очекивањима и образовним статусима, што мора бити узето у обзир у контексту пружања могућности за различите нивое интерпретација, а самим тим и развоја ефикасних модела за такву врсту истраживања.

Посебно је важно нагласити потребу да организатори оваквих догађаја морају у великој мери да нагласе емоционални аспект у програму догађаја, јер управо тај аспект има врло важну улогу у мрачном туризму. Уметнички перформанси током комеморативних догађаја морали би се усредсредити на успостављање емоционалне везе са туристима/посетиоцима, али, наравно, без занемаривања образовног аспекта таквог догађаја (Димитровски и остали, 2017).

Резултати овог истраживања имају практичне импликације за организаторе оваквих догађаја, пошто комеморативни догађаји нису само места где људи одлазе да одају почаст жртвама, већ је у питању начин на који привући шири аудиторијум на такав један догађај. У развоју овог типа туризма, организатори морају посебну пажњу да обрате на одржање аутентичности оваквог места, посебно његовог природног окружења, које је неодвојиви део самог догађаја. Јединственост догађаја и пратећи уметнички програм су један од главних аспеката који условљавају организаторе у пажљивом планирању, јер управо од њиховог планирања и организовања догађаја зависи одржање и опстанак степена атрактивности за посетиоце, као и преношење јаких антиратних порука. С друге стране, маркетиншке активности треба свести на минимум, углавном из етичких разлога у контексту промовисања, односно промоције места на којима су се збиле разне трагедије. 